\title{
Identification of novel homologous microRNA genes in the rhesus
} macaque genome Junming Yue*1,2, Yi Sheng² and Kyle E Orwig*1,2

Address: ${ }^{1}$ Department of Obstetrics, Gynecology and Reproductive Sciences, University of Pittsburgh School of Medicine, Pittsburgh, PA, 15213, USA and ${ }^{2}$ Magee-Womens Research Institute and Foundation, Pittsburgh, PA, 15213, USA

Email: Junming Yue* - jyue@pdc.magee.edu; Yi Sheng - ysheng@pdc.magee.edu; Kyle E Orwig* - korwig@pdc.magee.edu

* Corresponding authors

Published: 10 January 2008

BMC Genomics 2008, 9:8 doi:10.1 |86/|47|-2164-9-8

This article is available from: http://www.biomedcentral.com/147/-2164/9/8

(c) 2008 Yue et al; licensee BioMed Central Ltd.

This is an Open Access article distributed under the terms of the Creative Commons Attribution License (http://creativecommons.org/licenses/by/2.0), which permits unrestricted use, distribution, and reproduction in any medium, provided the original work is properly cited.
Received: 24 August 2007

Accepted: 10 January 2008

\begin{abstract}
Background: MicroRNAs (miRNAs) are about 22 nucleotide (nt) endogenous small RNAs that negatively regulate gene expression. They are a recently described class of regulatory molecules that has biological implications for tumorigenesis, development, metabolism and viral diseases. To date, 533 miRNAs have been identified in human. However, only 7I miRNAs have been reported in rhesus macaque. The rhesus is widely used in medical research because of its genetic and physiological similarity to human. The rhesus shares approximately $93 \%$ similarity with human in genome sequences and miRNA genes are evolutionarily conserved. Therefore, we searched the rhesus genome for sequences similar to human miRNA precursor sequences to identify putative rhesus miRNA genes.

Results: In addition to 7I miRNAs previously reported, we identified 383 novel miRNA genes in the rhesus genome. We compared the total 454 miRNAs identified so far in rhesus to human homologs, 173 miRNA genes showed 100\% homology in precursor sequences between rhesus and human; The remaining $28 \mathrm{I}$ show more than $90 \%$, less than $100 \%$ homology in precursor sequences. Some miRNAs in the rhesus genome are present as clusters similar to human, such as miR-37I/ 373, miR-367/302b, miR-17/92, or have multiple copies distributed in the same or different chromosomes. RT-PCR analysis of expression of eight rhesus miRNA genes in rhesus tissues demonstrated tissue-specific regulation of expression.

Conclusion: Identification of miRNA genes in rhesus will provide the resources for analysis of expression profiles in various tissues by creating a rhesus miRNA array, which is currently not available for this species. Investigation of rhesus miRNAs will also expand our understanding of their biological function through miRNA knockout, knockdown or overexpression.
\end{abstract}

\section{Background}

MicroRNAs (miRNAs) are non-coding small endogenous RNAs with a length of about 22 nt that negatively regulate gene expression by degrading mRNA or impeding protein translation [1]. MiRNA genes are hosted in intronic, exonic or intergenic regions of the genome and are tran- scribed into primary miRNA (pri-miRNA) by polymerase II. The pri-miRNAs are processed into $\sim 70 \mathrm{nt}$ pre-miRNAs with a hairpin structure by a microprocessor complex composed of Drosha and Pasha [2-4]. The pre-miRNAs are then transported into the cytoplasm by exportin-5, where the RNAase III enzyme, Dicer, cleaves pre-miRNA 
into 22 nt mature miRNAs, which are recruited into the RNA induced silencing complex (RISC) localized in discrete cytoplasmic foci, P bodies [5-8]. The RISC targets the mRNAs by perfect match to degenerate the target transcripts or binds the 3'UTR through imperfect base-pairing to block protein translation [9]. Recently computational analysis suggests miRNA may also bind 5'UTR [10]. One miRNA may target more than a hundred genes [10]. The discovery of miRNAs has led us to rethink the conventional mechanisms of gene regulation, and current research is focused on understanding how these small molecules function in biological processes.

Experimental evidence reveals that miRNAs play important roles in a variety of diseases, such as cancer, diabetes, viral infection, cardiac diseases, as well as in stem cell biology [11-18]. Some miRNAs are present in the genome as clusters where multiple miRNAs are aligned in the same orientation and transcribed as a polycistronic structure, which may function synchronously and cooperatively. The human miR-17/92 cluster composed of 5 miRNAs (miR-17, 18, 19, 20, 92) was found to be related to tumorigenesis and promoted tumor angiogenesis through targeting the anti-angiogenic thrombospondin-1 (Tsp1) by miR-19 or connective tissue growth factor (CTGF) by miR18 to down-regulate their functions $[19,20]$. The cluster miR371/373, which is highly expressed in human testicular germ cell tumors, has been demonstrated to function as an oncogene and is capable of overcoming Ras-mediated senescence in human primary fibroblasts [21]. In undifferentiated human ES cells, this cluster is also highly expressed and down-regulated upon differentiation, implicating a role in regulating stem cell self-renewal and differentiation [18].

To date, 533 human miRNAs have been discovered, and the functions of some of them have been experimentally verified [22]. While rhesus is an outstanding model of human physiology, only 71 rhesus miRNAs have been reported and registered in the Wellcome Trust Sanger Institute miRBase [23-25]. The study of miRNA in this species lags far behind the mouse, rat and human as well as invertebrates and plants. There are no reports on miRNA functions in rhesus thus far. Recently, the whole rhesus genome was sequenced through an international collaboration, which provides an opportunity to dissect the genome and identify miRNA genes [26].

To facilitate the examination of miRNAs in rhesus, we used human pre-miRNA sequences to query the rhesus genomic database at UCSC Genome Bioinformatics [2729] for homologous rhesus sequences to predict potential miRNA genes. This approach is feasible because miRNA genes are evolutionarily conserved and the human and rhesus genomes share about 93\% identity [26,30].

\section{Results}

\section{MiRNA genes in the rhesus genome}

We searched the rhesus genome for potential miRNA genes orthologous to published human precursor miRNA sequences in the Wellcome Trust Sanger Institute miRBase [23]. In addition to homology with human miRNA sequences, the search criteria required that miRNA genes encode mature miRNAs with at least 16 base pairings in the stem of the hairpin and a low calculated free energy ($25 \mathrm{k} \mathrm{cal} / \mathrm{mol}$ ) to form a hairpin structure [31,32]. Based on these criteria, we identified 454 rhesus miRNA genes, including 383 novel miRNA genes and 71 that were previously reported [33] (see additional file 1, Table 1). Of 454 rhesus miRNA genes, 173 share $100 \%$ homology with the human pre-miRNA (Category A), 281 have $>90 \%$ and less than $100 \%$ homology with human precursor miRNA sequences (Category B, Table 1 ). While the majority of Category B putative rhesus miRNA sequences contained three or fewer mismatches compared with the mature human sequences, rhesus miRNA sequences (mm1-miR-) 220b, 518e, 557, 589, 625, 639, 650d had four mismatches. The detailed miRNA precursor sequences (shown as cDNA sequences for convenient analysis) and predicted hairpin structure for all 454 rhesus miRNA genes are listed in additional file 1. The 533 human miRNA gene sequences used to search the rhesus genome are available from the Wellcome Trust Sanger Institute miRBase [23].

\section{MiRNA gene clusters in rhesus genome}

MiRNA genes tend to be present as clusters in the genome [34,35]. Clusters were previously defined by Weber [36] as miRNA genes present in the same orientation and not separated by a transcriptional unit. Altuvia and colleagues [37] demonstrated that $42 \%$ of known human miRNA genes are arranged in clusters in the genome using a $3 \mathrm{~kb}$ threshold between two miRNA genes or $48 \%$ if the threshold is $10 \mathrm{~kb}$. We found that at least some rhesus miRNAs are also arranged in clusters in the rhesus genome. Here we listed three human miRNA clusters (Figure 1) that have been associated with specific functions in previous studies. These miRNA clusters are located in regions of the genome that display substantial evolutionary conservation among 17 vertebrate species listed in the UCSC Genome Bioinformatics database: [27-29,38]. Sequence

Table I: MiRNA Genes in Rhesus Genome

\begin{tabular}{cccccc}
\hline Species & Known & Novel $^{\mathrm{a}}$ & Total & $\mathbf{A}^{\mathrm{b}}$ & B $^{\mathrm{b}}$ \\
\hline Rhesus & $\left.7\right|^{\mathrm{c}}$ & 383 & 454 & $173 / 454$ & $28 \mathrm{I} / 454$ \\
\hline
\end{tabular}

a: Identified in current studies.

b: Category A: $100 \%$ homology with human precursors miRNA. Category B: greater than $90 \%$ and less than $100 \%$ homology between rhesus and human precursor sequences. c: Previous published rhesus miRNA genes [33] 


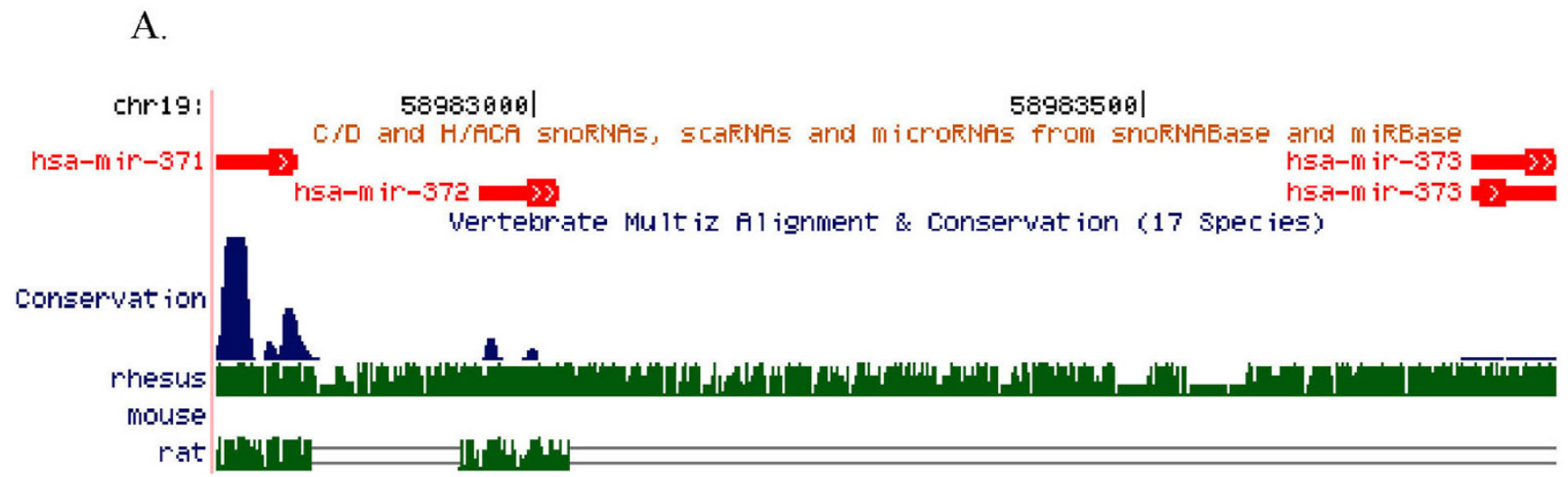

B.
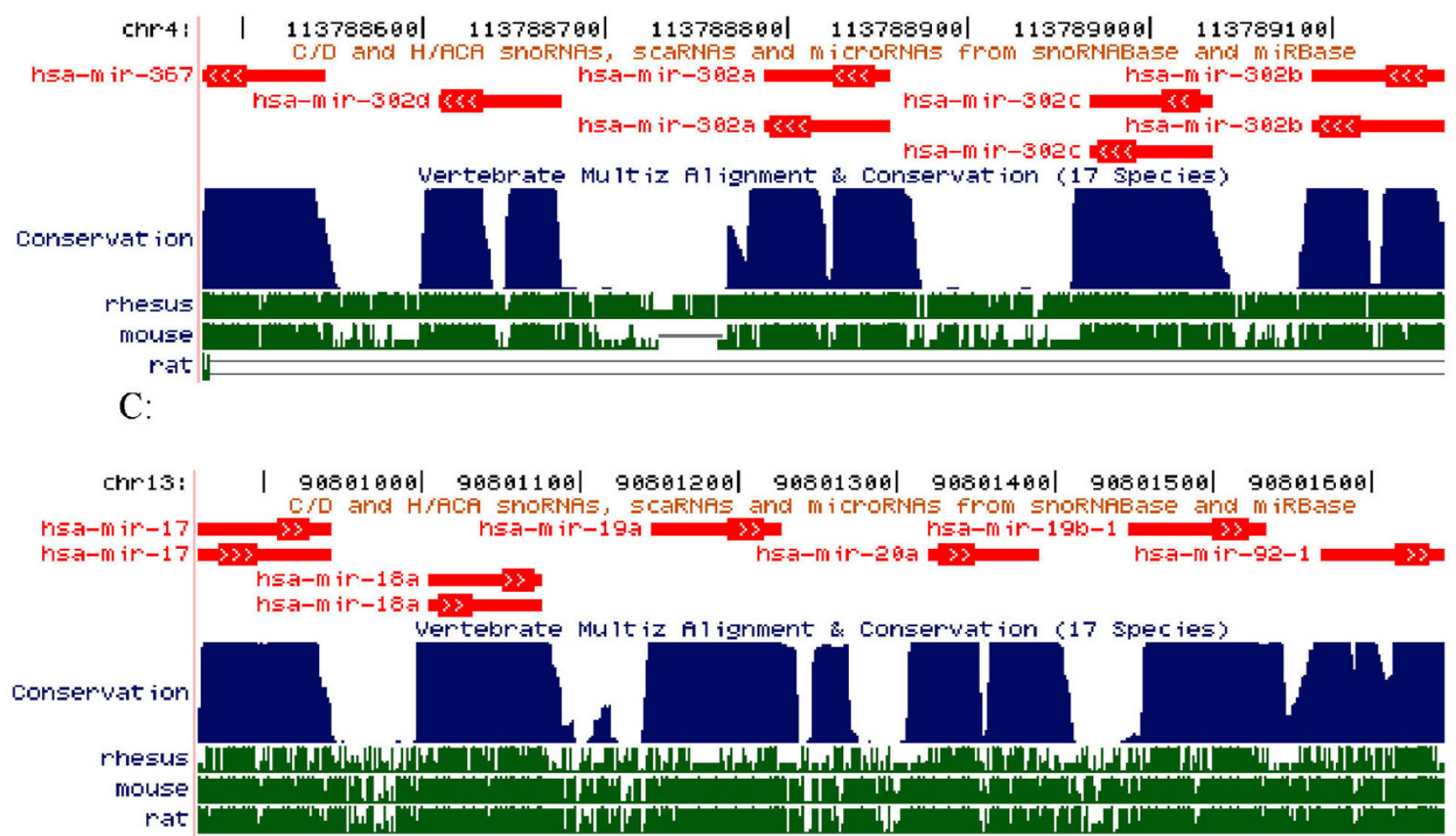

\section{Figure I}

MiRNA clusters in the human genome aligned with homologous regions of the rhesus, mouse and rat

genomes. (A) Human cluster miR-37I/373 is located on chr I9: 58,982,74I-58,983,839 (I099 bp, [27]), Rhesus has the similar cluster also located on chrl9 in rhesus. This cluster is not well conserved in mice and rats. (B) Human cluster miR-367/302b is on chr4: II3,926,634-I I3,927,3 I7 [27] and hosted in antisense orientation in a 684 bp region, in rhesus and mouse. There is no similar cluster in rat genome. (C) Human miR- I7/92 cluster is located on chr I3: 90,800,860-90,80I,646(787 bp, [27]) and is highly conserved among in the rhesus, mouse, and rat genomes.

conservation in these regions of the human genome with rhesus, mouse and rat are indicated (Figure 1). Cluster miR-371/373 is located on chromosome 19 in human and rhesus, is expressed in human ES cells [18] and functions as an oncogene in human testicular carcinomas [21]. Rhesus miR-372 and miR-373 have 100\% similarity in 
mature miRNA sequences with the human orthologs. Rhesus miR-371 has one nucleotide mismatch with the human sequence and rhesus miR-373* has three nucleotide differences (Table 2, Figure 1A). The mature sequences for miR-373 and miR-373* are encoded from the same pre-miRNA on complementary strands of the hairpin stem (see additional file 1).

Cluster miR-367/302b genes are expressed in human and mouse ES cells and down-regulated during development into embryoid bodies $[11,18]$. We found this cluster shares $100 \%$ homology in mature miRNA sequence between rhesus (located on chromosome 5) and human (located on chromosome 4). This cluster is also well con- served in mouse, but not in rat (Figure $1 \mathrm{~B}$, Table 2). Clusters miR-17/92 (Figure 1C, Table 2) is highly conserved among human, rhesus, mouse and rat and has been reported to function as oncogenes and promote tumorigenesis [19]. This cluster is hosted on chr13 in human and chrX in rhesus.

\section{Rhesus miRNA gene families}

Several Rhesus miRNA genes were considered family members based on sequence similarity criteria, as previously described [39]. The implications for miRNA gene amplification are still unknown, but miRNA genes with multiple copies may augment or amplify the physiological functions of individual miRNA genes. Among 454 rhe-

Table 2: Comparison of MiRNA Clusters in Human and Rhesus

\begin{tabular}{|c|c|c|c|}
\hline Clusters & MiRNA & Chr & Mature MiRNA Sequences $^{a}$ \\
\hline \multirow[t]{8}{*}{ MiR-37I/373 } & hsa-miR-37I & 19 & GUGCCGCCAUCUUUUGAGUGU \\
\hline & mml-miR-37I & 19 & GUGCCGCCAUGUUUUGAGUGU \\
\hline & hsa-miR-372 & 19 & AAAGUGCUGCGACAUUUGAGCGU \\
\hline & mml-miR-372 & 19 & AAAGUGCUGCGACAUUUGAGCGU \\
\hline & hsa-miR-373* & 19 & ACUCAAAAUGGGGGCGCUUUCC \\
\hline & mml-miR-373* & 19 & ACCCAAAAUGGGAGCACUUUCC \\
\hline & hsa-miR-373 & 19 & GAAGUGCUUCGAUUUUGGGGUGU \\
\hline & mml-miR-373 & 19 & GAAGUGCUUCGAUUUUGGGGUGU \\
\hline \multirow[t]{16}{*}{ MiR-367/302b } & hsa-miR-367 & 4 & AAUUGCACUUUAGCAAUGGUGA \\
\hline & mml-miR-367 & 5 & AAUUGCACUUUAGCAAUGGUGA \\
\hline & hsa-miR-302d & 4 & UAAGUGCUUCCAUGUUUGAGUGU \\
\hline & $\mathrm{mml}-\mathrm{miR}-302 \mathrm{~d}$ & 5 & UAAGUGCUUCCAUGUUUGAGUGU \\
\hline & hsa-miR-302a* & 4 & UAAACGUGGAUGUACUUGCUUU \\
\hline & mml-miR-302a* & 5 & UAAACGUGGAUGUACUUGCUUU \\
\hline & hsa-miR-302a & 4 & UAAGUGCUUCCAUGUUUUGGUGA \\
\hline & $\mathrm{mml}-\mathrm{miR}-302 \mathrm{a}$ & 5 & UAAGUGCUUCCAUGUUUUGGUGA \\
\hline & hsa-miR-302c* & 4 & UUUAACAUGGGGGUACCUGCUG \\
\hline & $\mathrm{mml}-\mathrm{miR}-302 \mathrm{c}^{*}$ & 5 & UUUAACAUGGGGGUACCUGCUG \\
\hline & hsa-miR-302c & 4 & UAAGUGCUUCCAUGUUUCAGUGG \\
\hline & mml-miR-302c & 5 & UAAGUGCUUCCAUGUUUCAGUGG \\
\hline & hsa-miR-302b* & 4 & ACUUUAACAUGGAAGUGCUUUCU \\
\hline & mml-miR-302b* & 5 & ACUUUAACAUGGAAGUGCUUUCU \\
\hline & hsa-miR-302b & 4 & UAAGUGCUUCCAUGUUUUAGUAG \\
\hline & $\mathrm{mml}-\mathrm{miR}-302 \mathrm{~b}$ & 5 & UAAGUGCUUCCAUGUUUUAGUAG \\
\hline \multirow[t]{14}{*}{ MiR-17/92 } & hsa-miR-17-5p & 13 & CAAAGUGCUUACAGUGCAGGUAGU \\
\hline & mml-miR-I7-5P & $x$ & CAAAGUGCUUACAGUGCAGGUAGU \\
\hline & hsa-miR-17-3p & 13 & ACUGCAGUGAAGGCACUUGU \\
\hline & mml-miR-17-3p & $x$ & ACUGCAGUGAAGGCACUUGU \\
\hline & hsa-miR-18a & 13 & UAAGGUGCAUCUAGUGCAGAUA \\
\hline & mml-miR-I8a & $x$ & UAAGGUGCAUCUAGUGCAGAUA \\
\hline & hsa-miR-19a & 13 & UGUGCAAAUCUAUGCAAAACUGA \\
\hline & mml-miR-19a & $x$ & UGUGCAAAUCUAUGCAAAACUGA \\
\hline & hsa-miR-20a & 13 & UAAAGUGCUUAUAGUGCAGGUAG \\
\hline & mml-miR-20a & $x$ & UAAAGUGCUUAUAGUGCAGGUAG \\
\hline & hsa-miR-I9b-I & 13 & UGUGCAAAUCCAUGCAAAACUGA \\
\hline & mml-miR-I9b-I & $x$ & UGUGCAAAUCCAUGCAAAACUGA \\
\hline & hsa-miR-92-I & 13 & UAUUGCACUUGUCCCGGCCUG \\
\hline & mml-miR-92-I & $\mathrm{x}$ & UAUUGCACUUGUCCCGGCCUG \\
\hline
\end{tabular}

a: Mismatches between rhesus and human sequences are indicated with bold letters. 
sus miRNA genes, 32 exist in families with two or more copies. Here we listed five miRNA gene families that are present as multiple copies in the genome (Table 3). MiRlet-7a, miR-7, miR-9, miR-513 and miR-220 families contain three or more copies distributed on the same or different chromosomes that produce identical or slightly differed mature miRNAs.

\section{Detection of mature miRNA from rhesus tissues by performing polyA tailing RT-PCR}

To test if the predicted miRNA genes generate mature miRNAs in adult rhesus tissues, 8 rhesus miRNAs were randomly selected from categories A and B (see Table 1 for category descriptions) and detected using the sensitive polyA tailing RT-PCR [40]. While miR-21, miR-30a and miR-373 were expressed in all 7 tissues including testis, kidney, lung, spleen, heart, liver and skeletal muscle, miR422, miR-28, miR-379, miR-431 and miR-648 demonstrated more restricted expression patterns (Figure 2).

\section{Discussion}

Based on homology searching of the rhesus genome by querying with human miRNA precursor sequences, we identified 454 miRNA genes, including 383 novel rhesus miRNAs, some of which are arranged in clusters as previously described for human. All of these miRNA genes and clusters are highly conserved between rhesus and human. RT-PCR analyses confirmed expression of rhesus miRNA genes in several tissues. Tissue specific regulation may indicate specialized roles in cell function and or tissue development. Stringent criteria were employed to identify the 454 rhesus miRNAs in this study and some additional miRNAs may yet be identified. While the rhesus genome was recently sequenced, it has not been fully assembled. In addition, rhesus miRNA genes were identified based on human orthologs, which may fail to identify some rhesus specific miRNAs and putative miRNA genes identified in this study contained at least a $16 \mathrm{nt}$ pairing in the stem arm of the hairpin structure of the mature miRNA [31]. We frequently encounter 13 to $15 \mathrm{nt}$ pairings in this core region from the predicted hairpin structure. We didn't consider them as novel miRNA genes in this study, but they could be potential miRNA genes. For example, hsamiR-484 and bta-miR-484 have $15 \mathrm{nt}$ and $12 \mathrm{nt}$ pairings in stem arm of hairpin structure, respectively. Both hsamiR-484 and bta-miR-484 have been verified experimentally as miRNA genes in human and bovine, respectively [22].

While we were writing this manuscript, Zhang et al. reported rhesus miR-506, 507, 508, 509-1, 509-2, 510 and 514 sequences [41]. These sequences are also predicted in the current study, although there were some differences in nomenclature. We employed the systematic annotation previously described for miRNAs [31].

\section{Conclusion}

In the current study we identified 454 rhesus miRNA genes, including 71 that were previously reported. Identification of miRNA genes from rhesus will eventually pro-

Table 3: Rhesus MiRNA Gene Families

\begin{tabular}{|c|c|c|c|c|}
\hline MiRNA & Mature MiRNAa & Chr & Strand & Positions in Chrb \\
\hline mml-miR-let-7a-I & UGAGGUAGUAGGUUGUAUAGUU & 15 & + & $105917273-105917352$ \\
\hline mml-miR-let-7a-2 & & 14 & - & $120554305-120554376$ \\
\hline mml-miR-let-7a-3 & & 10 & + & $90121100-90121173$ \\
\hline mml-miR-7-I & UGGAAGACUAGUGAUUUUGUUG & 15 & - & $92701750-92701859$ \\
\hline mml-miR-7-2 & & 7 & + & $68219893-68220002$ \\
\hline mml-miR-7-3 & & 19 & + & $4659068-4659177$ \\
\hline mml-miR-9-I & UCUUUGGUUAUCUAGCUGUAUGA & 1 & - & $|35024723-1350248| \mid$ \\
\hline mml-miR-9-2 & & 6 & - & $849554 \mid I-84955497$ \\
\hline mml-miR-9-3 & & 7 & + & $68995340-68995429$ \\
\hline mml-miR-5I3-I & UUCACAGGGAGGUGUCAUUUAU & $\mathrm{X}$ & - & |45346049-|45346|77 \\
\hline mml-miR-5। 3-2 & & $\mathrm{X}$ & - & $|45354602-| 45354730$ \\
\hline mml-miR-5l3-3 & & $x$ & - & |45337083-|453372| 4 \\
\hline mml-miR-202a & CCACCACCAUGUCUGACACUUU & $x$ & - & $|2| 787204-1217873 \mid 4$ \\
\hline mml-miR-202b & CCACCACCGUGUCCGACACCUU & 18 & + & $2383348-2383458$ \\
\hline $\mathrm{mml}-\mathrm{miR}-202 \mathrm{c}$ & CCACCACUGUGUCUGACACCUU & 20 & - & $8805874 \mid-88058838$ \\
\hline $\mathrm{mml}-\mathrm{miR}-202 \mathrm{~d}$ & CCACCACCGUGUCUGACACCUU & 4 & + & $3002388-3002492$ \\
\hline
\end{tabular}

a: Individual genes within a miRNA gene family have the same or different mature miRNA sequences (bold letters indicate the different nucleotides comparing with the mml-miR-202a).

b: position of rhesus miRNA genes in the genome can be found at [27]. 


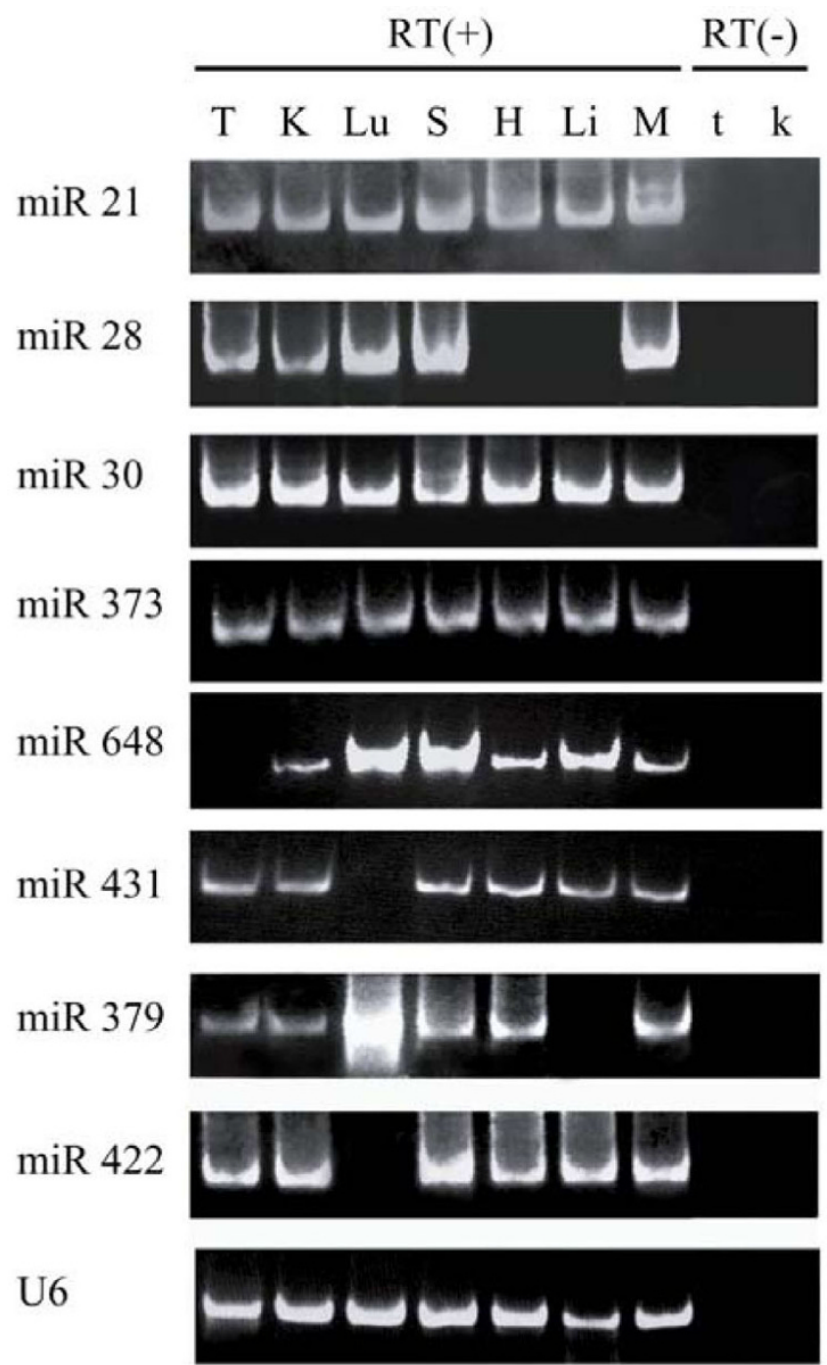

Figure 2

Selected mature miRNA expression profiles in rhesus tissues. PolyA tailing RT-PCR was used to detect miRNA expression in adult rhesus different tissues. T: testis, K: kidney, Lu: lung, S: spleen, H: heart, Li: liver, M: Skeletal muscle, t: RT(-) control from testis, k: RT(-) control from kidney. U6 snRNA was amplified as an internal control.

vide the resources for analysis of expression profiles via microarray. These tools will help identify candidate miRNA genes associated with specific tissues, cells or biological functions.

\section{Methods}

\section{Bioinformatics analysis}

Human Pre-miRNA sequences were downloaded from Wellcome Trust Sanger Institute miRBase, release $\mathbf{1 0 . 0}$ [22-24] and used to search the rhesus genome at UCSC Genome Bioinformatics [27-29,38] for homologous sequences. Chromosomal location of putative rhesus
miRNAs was determined at UCSC Genome Bioinformatics [27-29,38]. ClustalW [28,42,43] was used for sequences alignment. Precursor sequences were analyzed for secondary structure using MFOLD [44,45].

\section{PolyA tailing RT-PCR}

Total RNA was extracted from the heart, liver, lung, kidney, skeletal muscle, spleen and testes of rhesus macaques with Trizol Reagent (Invitrogen, Carlsbad, CA). For polyA tailing RT-PCR, $5 \mu \mathrm{g}$ total RNA from each tissue was treated with DNase(Invitrogen, Carlsbad, CA) and then polyadenylated using polyA polymerase (PAP, Ambion, Austin, TX) according to the manufacturer's instructions. The final reaction mixtures were extracted with phenol/ chloroform, precipitated with ethanol and redisolved into $20 \mu$ diethylpyrocarbonate(DEPC)-treated water. Half of the polyA tailed RNA was reverse transcribed into firststrand cDNA using Superscript III transcriptase (Invitrogen, Carlsbad, CA) with the oligodT adapter primer: 5'GCGAGCACAGAATTAATACGACTCACTATAG-

GTTTTTTTTTTTTVN-3'. The remaining RNA was used for RT control without reverse transcriptase. For PCR, 2 ul of RT products were used as templates in each reaction. The reverse primer for each miRNA was from the same tailing sequences: 5'-TTCACGAATTTGCGTGTCAT-3'. The forward primers were specific to miRNA mature sequences, and U6 snRNA sequences were listed in Table 4 . The PCR conditions were initially denatured at $94^{\circ} \mathrm{C}$ for $3 \mathrm{~min}$ followed by 30 cycles of $94^{\circ} \mathrm{C}$ for $30 \mathrm{sec}, 60^{\circ} \mathrm{C}$ for $45 \mathrm{sec}$ and $72^{\circ} \mathrm{C}$ for $30 \mathrm{sec}$, final extension for $5 \mathrm{~min}$ at $72^{\circ} \mathrm{C}$. PCR products were separated on $12 \%$ native polyacrylamide gels and stained with ethidium bromide. U6 snRNA was amplified as an internal control.

\section{Authors' contributions}

JY performed the genomic search and wrote the initial draft of manuscript. YS did RT-PCR and edited the draft. KEO provided experimental resources and advice and edited the final manuscript. All authors read and approved the final manuscript.

Table 4: Primer Sequences for PolyA Tailing RT-PCR

\begin{tabular}{ll}
\hline \multicolumn{1}{c}{ MiRNA } & \multicolumn{1}{c}{ Primer Sequences } \\
\hline mml-miR-2I & TAGCTTATCAGACTGATGTTGA \\
mml-miR-30a & TGTAAACATCCTCGACTGGAAG \\
mml-miR-28 & AAGGAGCTCACAGTCTATTGAG \\
mml-miR-373 & ACCCAAAATGGGAGCACTTTCC \\
mml-miR-379 & TGGTAGACTATGGAACGTA \\
mml-miR-422a & CTGGACTCAGGGTCAGAAGGCC \\
mml-miR-43I & TGTCTTGCAGGCCGTCATGCA \\
mml-miR-648 & AAGTGTGCAGGGCACTGAT \\
U6 Forward & GCTTGCTTCGGCAGCACATATAC \\
U6 Reverse & TGCATGTCATCCTTGCTCAGGG \\
\hline
\end{tabular}




\section{Additional material}

\section{Additional file 1}

Pre-miRNA sequences in the rhesus genome and predicted secondary structures. The figure provides the pre-miRNA sequence and predicted secondary structure of 454 putative rhesus miRNA genes identified in the current study based on homology with human miRNA sequences. Click here for file

[http://www.biomedcentral.com/content/supplementary/14712164-9-8-S1.pdf]

\section{Acknowledgements}

We acknowledge Dr. Ahmi Ben-Yehudah (University of Pittsburgh) for helpful discussions and Dr. Ronald H Plasterk (Utrecht University, The Netherlands) for review of this manuscript prior to publication. The research was supported by the Magee-Womens Research Institute and Foundation (JY, YS and KEO) and National Institutes of Health grants RRI8500, AG024992, HDOI29I3, HD0086I0 (KEO).

\section{References}

I. Dennis C: Small RNAs: The genome's guiding hand? Nature 2002, 420:732-732.

2. Gregory RI, Yan K, Amuthan G, Chendrimada T, Doratotaj B, Cooch N, Shiekhattar R: The Microprocessor complex mediates the genesis of microRNAs. Nature 2004, 432:235-240.

3. Denli AM, Tops BB], Plasterk RHA, Ketting RF, Hannon G]: Processing of primary microRNAs by the Microprocessor complex. Nature 2004, 432:23I-235.

4. Chendrimada TP, Gregory RI, Kumaraswamy E, Norman J, Cooch N, Nishikura K, Shiekhattar R: TRBP recruits the Dicer complex to Ago 2 for microRNA processing and gene silencing. Nature 2005, 436:740-744.

5. Yi R, Qin Y, Macara IG, Cullen BR: Exportin-5 mediates the nuclear export of pre-microRNAs and short hairpin RNAs. Genes Dev 2003, 1 7:3011-3016.

6. Jakymiw A, Lian S, Eystathioy T, Li S, Satoh M, Hamel JC, Fritzler MJ, Chan EK: Disruption of GW bodies impairs mammalian RNA interference. Nat Cell Biol 2005, 7:1267-1274.

7. Yang Z, Jakymiw A, Wood MR, Eystathioy T, Rubin RL, Fritzler MJ, Chan EKL: GWI 82 is critical for the stability of $\mathbf{G W}$ bodies expressed during the cell cycle and cell proliferation. J Cell Sci 2004, I I 7:5567-5578.

8. Bohnsack MT, Czaplinski K, Gorlich D: Exportin 5 is a RanGTPdependent dsRNA-binding protein that mediates nuclear export of pre-miRNAs. RNA 2004, 10:185-19|

9. Ambros $V$ : The functions of animal microRNAs. Nature 2004 $431: 350-355$.

10. Miranda KC, Huynh T, Tay Y, Ang YS, Tam WL, Thomson AM, Lim B, Rigoutsos I: A Pattern-Based Method for the Identification of MicroRNA Binding Sites and Their Corresponding Heteroduplexes. Cell 2006, I 26:1203-1217.

II. Houbaviy HB, Murray MF, Sharp PA: Embryonic Stem Cell-Specific MicroRNAs. Developmental Cell 2003, 5:35 I-358.

12. Conrad R, Barrier M, Ford LP: Role of miRNA and miRNA processing factors in development and disease. Birth Defects Res C Embryo Today 2006, 78:107-1 I7.

13. McManus MT: MicroRNAs and cancer. Semin Cancer Biol 2003 I 3:253-258.

14. Jin P, Zarnescu DC, Ceman S, Nakamoto M, Mowrey J, Jongens TA Nelson DL, Moses K, Warren ST: Biochemical and genetic interaction between the fragile $X$ mental retardation protein and the microRNA pathway. Nat Neurosci 2004, 7: I I3-1 I7.

15. Hossain A, Kuo MT, Saunders GF: Mir-17-5p Regulates Breast Cancer Cell Proliferation by Inhibiting Translation of AIB mRNA. Mol Cell Biol 2006, 26:8191-820I.

16. Burnside J, Bernberg E, Anderson A, Lu C, Meyers BC, Green PJ, Jain N, Isaacs G, Morgan RW: Marek's Disease Virus Encodes Micro-
RNAs That Map to meq and the Latency-Associated Transcript. J Virol 2006, 80:8778-8786.

17. Zhao Y, Samal E, Srivastava D: Serum response factor regulates a muscle-specific microRNA that targets Hand2 during cardiogenesis. Nature 2005, 436:214-220.

18. Suh MR, Lee Y, Kim JY, Kim SK, Moon SH, Lee JY, Cha KY, Chung HM, Yoon HS, Moon SY, Kim VN, Kim KS: Human embryonic stem cells express a unique set of microRNAs. Developmental Biology 2004, 270:488-498.

19. He L, Thomson JM, Hemann MT, Hernando-Monge E, Mu D, Goodson S, Powers S, Cordon-Cardo C, Lowe SW, Hannon GJ, Hammond SM: A microRNA polycistron as a potential human oncogene. Nature 2005, 435:828-833.

20. Dews M, Homayouni A, Yu D, Murphy D, Sevignani C, Wentzel E, Furth EE, Lee WM, Enders GH, Mendell JT, Thomas-Tikhonenko A: Augmentation of tumor angiogenesis by a Myc-activated microRNA cluster. Nat Genet 2006, 38:1060-1065.

21. Voorhoeve PM, le Sage C, Schrier M, Gillis AJM, Stoop H, Nagel R, Liu YP, van Duijse J, Drost J, Griekspoor A, Zlotorynski E, Yabuta N, De Vita G, Nojima H, Looijenga LHJ, Agami R: A Genetic Screen Implicates miRNA-372 and miRNA-373 As Oncogenes in Testicular Germ Cell Tumors. Cell 2006, I 24: I I69-I I8I.

22. Griffiths-Jones S: miRBase: the microRNA sequence database. In MicroRNA Protocols Edited by: S-Y Y. Totowa, NJ, Humana Press, Inc.; 2006: I29-I38.

23. Wellcome Trust Sanger Institute miRBase 2008 [http://micro rna.sanger.ac.uk/cgi-bin/sequences/browse.pl].

24. Griffiths-Jones S, Grocock RJ, van Dongen S, Bateman A, Enright AJ: miRBase: microRNA sequences, targets and gene nomenclature. Nucl Acids Res 2006, 34:DI40-DI44.

25. Griffiths-Jones S: The microRNA Registry. Nucl Acids Res 2004, 32:DI09-DIII.

26. Gibbs RA, Rogers J, Katze MG, Bumgarner R, Weinstock GM, Mardis ER, Remington KA, Strausberg RL, Venter JC, Wilson RK, Batzer MA, Bustamante CD, Eichler EE, Hahn MW, Hardison RC, Makova KD, Miller W, Milosavljevic A, Palermo RE, Siepel A, Sikela JM, Attaway T, Bell S, Bernard KE, Buhay CJ, Chandrabose MN, Dao M, Davis C, Delehaunty KD, Ding Y, Dinh HH, Dugan-Rocha S, Fulton LA, Gabisi RA, Garner TT, Godfrey J, Hawes AC, Hernandez J, Hines S, Holder M, Hume J, Jhangiani SN, Joshi V, Khan ZM, Kirkness EF, Cree A, Fowler RG, Lee S, Lewis LR, Li Z, Liu Y, Moore SM, Muzny D, Nazareth LV, Ngo DN, Okwuonu GO, Pai G, Parker D, Paul HA, Pfannkoch C, Pohl CS, Rogers YH, Ruiz SJ, Sabo A, Santibanez J, Schneider BW, Smith SM, Sodergren E, Svatek AF, Utterback TR, Vattathil S, Warren W, White C, Chinwalla AT, Feng $Y$, Halpern AL, Hillier LDW, Huang X, Minx P, Nelson JO, Pepin KH, Qin X, Sutton GG, Venter E, Walenz BP, Wallis JW, Worley KC, Yang SP, Jones SM, Marra MA, Rocchi M, Schein JE, Baertsch R, Clarke L, Csuros M, Glasscock J, Harris RA, Havlak P, Jackson AR, Jiang $H$, Liu $Y$, Messina DN, Shen Y, Song HXZ, Wylie T, Zhang L, Birney E, Han K, Konke MK, Lee J, Smit AFA, Ullmer B, Wang H, Xing J, Burhans R, Cheng Z, Karro JE, Ma J, Raney B, She X, Cox MJ, Demuth JP, Dumas LJ, Han SG, Hopkins J, Karimpour-Fard A, Kim YH, Pollack JR, Vinar T, ddoQuaye C, Degenhardt J, Denby A, Hubisz MJ, Indap A, Kosiol C, Lahn BT, Lawson HA, Marklein A, Nielsen R, Vallender EJ, Clark AG, Ferguson B, Hernandez RD, Hirani K, Kehrer-Sawatzki H, Kolb J, Patil S, Pu LL, Ren Y, Smith DG, Wheeler DA, Schenck I, Ball EV, Chen R, Cooper DN, Giardine B, Hsu F, Kent WJ, Lesk A, Nelson DL, O'Brien WE, Prufer K, Stenson PD, Wallace JC, Ke H, Liu XM, Wang P, Xiang AP, Yang F, Barber GP, Haussler D, Karolchik D, Kern AD, Kuhn RM, Smith KE, Zwieg AS: Evolutionary and Biomedical Insights from the Rhesus Macaque Genome. Science 2007, 3 I 6:222-234.

27. UCSC Genome Bioinformatics 2008 [http://genome.ucsc.edu/].

28. Kent WJ, Sugnet CW, Furey TS, Roskin KM, Pringle TH, Zahler AM, Haussler D: The Human Genome Browser at UCSC. Genome Res 2002, 12:996-1006.

29. Karolchik D, Baertsch R, Diekhans M, Furey TS, Hinrichs A, Lu YT, Roskin KM, Schwartz M, Sugnet CW, Thomas DJ, Weber RJ, Haussler D, Kent W]: The UCSC Genome Browser Database. Nucl Acids Res 2003, 31:51-54.

30. Stewart $C B$, Disotell TR: Primate evolution - in and out of Africa. Current Biology 1998, 8:R582-R588.

31. Ambros V, Bartel B, Bartel DP, Burge CB, Carrington JC, Chen X, Dreyfuss G, Eddy SR, Griffiths-Jones S, Marshall M, Matzke M, Ruvkun $\mathrm{G}$, Tuschl T: A uniform system for microRNA annotation. RNA 
2003, 9:277-279 [http://www.rnajournal.org/cgi/content/abstract/9/3/ 277]

32. Xue C, Li F, He T, Liu GP, Li Y, Zhang X: Classification of real and pseudo microRNA precursors using local structuresequence features and support vector machine. BMC Bioinformatics 2005, 6:310.

33. Berezikov E, Guryev V, van de Belt J, Wienholds E, Plasterk RHA, Cuppen E: Phylogenetic Shadowing and Computational Identification of Human microRNA Genes. Cell 2005, I 20:2 I-24.

34. Lagos-Quintana M, Rauhut R, Lendeckel W, Tuschl T: Identification of Novel Genes Coding for Small Expressed RNAs. Science 200I, 294:853-858.

35. Lagos-Quintana M, Rauhut R, Meyer J, Borkhardt A, Tuschl T: New microRNAs from mouse and human. RNA 2003, 9:175-179.

36. Weber MJ: New human and mouse microRNA genes found by homology search. FEBS Journal 2005, 272:59-73.

37. Altuvia $Y$, Landgraf $P$, Lithwick $G$, Elefant $N$, Pfeffer $S$, Aravin A Brownstein MJ, Tuschl T, Margalit $\mathrm{H}$ : Clustering and conservation patterns of human microRNAs. Nucl Acids Res 2005, 33:2697-2706

38. Kent W]: BLAT---The BLAST-Like Alignment Tool. Genome Res 2002, I 2:656-664.

39. Dostie J, Mourelatos Z, Yang M, Sharma A, Dreyfuss G: Numerous microRNPs in neuronal cells containing novel microRNAs. RNA 2003, 9:180-186.

40. Shi R, Chiang VL: Facile means for quantifying microRNA expression by real-time PCR. Biotechniques 2005, 39:5 I9-525.

4I. Zhang R, Peng Y, Wang W, Su B: Rapid evolution of an X-linked microRNA cluster in primates. Genome Res 2007, 17:6/2-617.

42. ClustalW 2008 [http://www.ebi.ac.uk/clustalw/].

43. Myers EW, Miller W: Optimal alignments in linear space. Comput Appl Biosci 1988, 4: I I-I7.

44. MFOLD 2008 [http://www.bioinfo.rpi.edu/applications/mfold].

45. Zuker M: Mfold web server for nucleic acid folding and hybridization prediction. Nucl Acids Res 2003, 31:3406-34I 5.

Publish with Bio Med Central and every scientist can read your work free of charge

"BioMed Central will be the most significant development for disseminating the results of biomedical research in our lifetime. "

Sir Paul Nurse, Cancer Research UK

Your research papers will be:

- available free of charge to the entire biomedical community

- peer reviewed and published immediately upon acceptance

- cited in PubMed and archived on PubMed Central

- yours - you keep the copyright 